\title{
Yellow Fever Virus Antibody Measurement
}

National Cancer Institute

\section{Source}

National Cancer Institute. Yellow Fever Virus Antibody Measurement. NCI Thesaurus.

Code C147450.

The determination of the amount of Yellow Fever virus antibody present in a sample. 